\title{
SHRIMP CULTURE PRACTICES AT FARMERS' LEVEL IN BAGERHAT DISTRICT
}

\author{
K. J. Chandra*, A. R. Chowdhury and D. R. Das \\ Department of Aquaculture, Faculty of Fisheries, Bangladesh Agricultural University \\ Mymensingh-2202, Bangladesh
}

\begin{abstract}
A study was conducted on culture practices of shrimp at farmers' level in Bagerhat District. Investigation was based on a sample of 123 shrimp farmers from the seven Thanas (Fakirhat, Mollahat, Sadar, Rampal, Mongla, Chitalmari and Kachua) of the District, $73.17 \%$ farmers produced shrimp with white fishes. Farmers (54.47\%) started to culture during 2000-2004 in this area. The culture period was typically four months for bagda and six to seven months for golda. Hatchery PL are stocked mainly in May to June for prawn and from late March for bagda. The average stocking density of shrimp PL golda and bagda was 24.16 and 12.16 thousand/ha in the farms. Varieties of feeds such as cooked rice, fishmeal, oilcake and snail muscle were used for shrimp culture. Mainly virus disease was responsible for the great loss of shrimp in this area. About $46.34 \%$ of the surveyed farms faced a huge damage due to WSBV. The average bagda and golda production was $350.37 \mathrm{~kg}$ and $428.08 \mathrm{~kg} / \mathrm{ha} /$ year. Long term sustainability of shrimp farming facing problems due to lack of money, poor supply of good quality PL, lack of technical knowledge, higher production costs and poor institutional support. It might be however, necessary to establish shrimp hatcheries and provide training facilities, extension service, institutional and policy support to the farmers with the help of DoF and NGOs.
\end{abstract}

Key Words: Shrimp culture, Gher, Virus diseases, Production

\section{INTRODUCTION}

Prawn and tiger shrimp are generally called shrimp in the southern part of Bangladesh. In this region, freshwater aquaculture is virtually limited for the farming of Macrobrachium rosenbergii (prawn) and brackish water aquaculture of Penaeus monodon (tiger shrimp) together with carps or integrated culture with paddy. Macrobrachium rosenbergii is one of the most commercially valued species for aquaculture (Mitra et al., 2005). It is widely distributed in freshwater as well as in brackish water, mainly in ponds, rivers, canals and estuaries (Ahmed, 1957). There are about 81 species of shrimps including $M$. rosenbergii, $P$. monodon, $P$. merguiensis and $P$. durarum are available in southeast Asian countries. However, $P$. monodon and $M$. rosenbergii have got great aquaculture potential and commercially cultured in Bangladesh (Akand and Hasan,1992). Presently

\footnotetext{
* Corresponding Address. E-mail : kirtuniajchandra@yahoo.com
} 
prawn is commercially cultured in the costal districts and these areas have become the centers for prawn farming in Bangladesh. Moreover, there is $710 \mathrm{~km}$ long coast line along the south-eastern part of our country. In this vast area of brackish water body, tiger shrimp culture has been expanded. Bagerhat district is one of this area where tiger shrimp farming has been cultured extensively in Rampal, Mongla and a portion of Fakirhat Thana (Khanom, 1999). According to Islam (1999), the culture area of prawn is estimated as 6,000 hectares of which 3,261 hectares are located in Bagerhat district, whereas 1,429 hectares in Fakirhat Thana. Earlier most of the farmers used to cultivate their farms by traditional method. But now a days most of the farmers' culture shrimps in their farms by traditional, improved traditional or semi-intensive methods. Although there is a bright prospect of tiger shrimp culture in our country, planned action program has not yet been taken. For tiger shrimp culture most of the farmers act as small land holder. If they are provided with technical assistance production of shrimp can be increased manifolds. Commercial prawn farming has recently taken place in Bagerhat area in ghers.

The gher is an enclosure made for shrimp cultivation by modifying rice-fields through building higher dikes around the fields and excavating a canal several feet deep inside the periphery of the dikes to enter water during the dry season (Kendrick, 1994). According to DFID (1997), gher farming can be considered as a method of combining aquaculture and agriculture on one plot. During the rainy season the whole water body is used for cultivation of shrimp and fish. However, during dry seasons the trenches are used for shrimp and fish culture and rice is planted in the central plot. Shrimp especially prawn can be cultured with carps in low lying paddy fields, shallow ponds, shallow portion of baor, canal beside road and rail line and irrigated canals of fresh water bodies (Khanom, 1999). Shrimp yield in ghers can be increased by applying modern technology such as intensification of culture operation through regularization of gher size, stocking density, adding aeration system, application of fertilization and feeds. Considering the back drop of the state of affairs of shrimp farming, in general the present study was undertaken to investigate the present status of shrimp culture and also to understand the different characteristics of shrimp culture practices in Bagerhat district.

\section{MATERIALS AND METHODS}

The study was carried out in seven Thanas namely, Fakirhat, Mollahat, Chitalmari, Sadar, Kachua, Rampal and Mongla in Bagerhat district. The ghers (farms) were selected randomly from each Thana. The survey was conducted over three months (January to March 2007) in the study areas where the study was mainly concentrated on the category of shrimp farming, types, culture techniques and physical condition of the farms such as dike condition and ownership patterns, depth of water and problems during culture time. Data related to pre-stocking management including presence or absence of drying, liming and fertilization were collected. Information on stocking including place PL collection, stocking density of PL, feeding, liming, manuring, water quality and presence or absence of aquatic weeds during culture period were collected. A questionnaire was 
prepared for collection of relevant information in accordance with the objectives. Both open and closed form of questions was used to collect information. Simple and direct questions were included in the questionnaire to ascertain the opinion of the shrimp farmers. Data were collected by questionnaire interviewing of 123 shrimp farmers in the seven selected Thanas. Farmers were selected for questionnaire interview through random sampling and Participatory Rural Appraisal (PRA) tools like Large Group Discussion (LGD), Focus Group Discussion (FGD) and Cross-Check interviews with Key Information (KI). Besides primary information study, secondary data were collected from different sources, such as books and journals, Export promotion Bureau (EPB), Department of Fisheries (DoF), Statistical year book of Bangladesh (2001), relevant thesis, reports, official records, newspapers and library etc. Collected information obtained from the survey was accumulated, grouped and interpreted according to the objectives as well as parameters. Some data have contained numeric and narrative facts. The collected data were then edited, summarized and tabulated and analyzed by Microsoft Excel and Statistical Package for Social Science (SPSS).

\section{RESULTS AND DISCUSSION}

Fish farmers of Bagerhat district used both natural and hatchery post larvae (PL) in their farms. Only 20\% farmers of Fakirhat Thana released naturally collected PL and farmers of other Thana did not stock any PL of natural resource. Farmers of Mongla and Kachua Thana (60\% of each) used hatchery produced PL whereas $80 \%$ farmers in Rampal and $75 \%$ farmers in Mollahat Thana released both natural and hatchery PL. Post larvae were collected either from arat ( Business establishment with storage facilities for selling and purchasing ) of PL mockams (Business centre, place where located a number of arats). There were five PL mockams (Faila, Rampal, Digraj, Chila and Faltita bazar mockam) in the study areas. It has been found that $52.85 \%$ of farmers collected PL from arats, $47.15 \%$ collected through forias (Man, who purchases from producers and sells to buyers) and other collected directly from hatchery. It was also observed that natural PL were collected mainly from Chila and Digraj bazar mokam and hatchery PL from Faila, Rampal, Digraj, Chila and Faltita bazar mockam through forias. Buyers of far away carried shrimp PL with cock-sheet containers, while local buyers (forias) carried PL in aluminium pots to the local areas or to long distances as per contract. It was found that PL were transported with both cock-sheet box and aluminium pot used by $53.66 \%$ farmers (buyers) (Table 1 ).

Shrimp farming was not a very old practice in Bagerhat district. Among the interviewed farmers only $8.95 \%$ started shrimp farming before 1995 . About $30.80 \%, 54.47 \%$ and $6.50 \%$ farmers started shrimp farming in the year ranging 1995-99, 2000-04 and after 2004 respectively. The highest number of farms $(80 \%)$ was established in the year between of 2000 to 2004 in Sadar Thana. No farms were established in Mollahat, Chitalmari, Sadar, Kachua before 1995 and Sadar, Chitalmari after 2004. Interviewed farmers stated that they started shrimp cultivation to earn more money as shrimp farming was profitable than agriculture. 


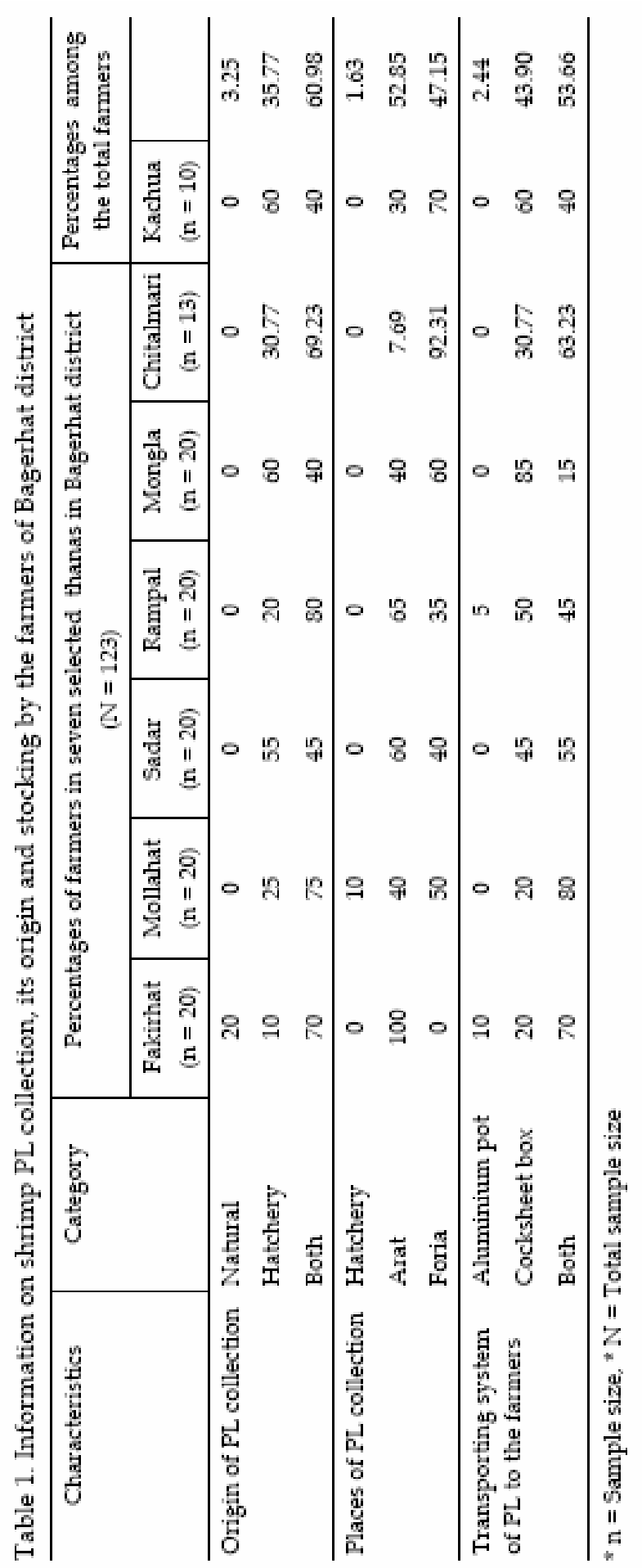


Size of maximum $(67.48 \%)$ shrimp farms was between 1 to 5 acres. It was observed that very small numbers $(18.70 \%)$ of farms were below 1 acre and above 5 acres were $13.82 \%$. The highest number of larger farms i.e. more than 5 acres was found in Mongla and less than 1 acre in Sadar Thana. Farms were operated by both single and multiple owners, $54.47 \%$ farms had single owner and the rest $45.53 \%$ farms had multiple owner. Single ownership was higher (85\%) in Fakirhat Thana and lower (25\%) in Rampal Thana.

Some farmers were found to culture shrimp PL in their own land and some used leased pond. A few farmers used both own and leased land for PL culture. It was found that $39.84 \%$ farmers used own land for PL culture while 53.64\% and 6.50\% farmers used leased and both own and leased land respectively. In Fakirhat 65\% and in Mongla 70\% farmers cultured shrimp in their own and leased land. Leasing cost in general was estimated at Tk. 4,000-14,000 per acre per year in the study area.

In the study area $36.59 \%$ farmers cultured tiger shrimp (bagda) and freshwater prawn (golda) PL. However, among the surveyed farms 33.33\% farmers cultured bagda and $30.08 \%$ cultured golda PL. It was also observed that almost $100 \%$ farmers cultured bagda PL in Mongla Thana but bagda PL was cultured in Fakirhat, Mollahat and Chitalmari Thana. Most of the farmers $85 \%$ cultured golda in Mollahat Thana.

It was found that $73.17 \%$ farmers cultured shrimp with white fishes whereas only $26.83 \%$ surveyed farmers cultured only shrimp (bagda and golda) i.e. monoculture system. The maximum monoculture system was found in Mongla Thana $(85 \%)$. Whereas in Chitalmari almost $100 \%$ farms were under polyculture system.

About $9.76 \%$ farms had good dikes whereas $45.53 \%$ and $44.72 \%$ farms had moderate and damaged dikes respectively. It was also found that no good dikes were observed in Sadar, Mongla and Kachua Thana. About 80\% farms in Mongla and Kachua Thana were found damaged dikes (Table 2).

\section{Pre and post stocking management of the shrimp farm}

In the study area, it was found that as pre-stocking management $54.47 \%$ farms were dried. Maximum 75\% farms were dried in Fakirhat whereas 65\% farmers in Sadar Thana did not dry their farms. In pre-stocking management $18.70 \%$ and $21.14 \%$ farmers applied only organic manure and inorganic fertilizer respectively. In Fakirhat Thana, 80\% farmers used fertilizers after stocking but in Mongla Thana about $85 \%$ farmers did not use any fertilizers. Farmers, $69.92 \%$ used lime at different doses. Lime was used by $80 \%$ farmers in Mollahat and Rampal whereas $60 \%$ farmers of Kachua Thana did not use lime. About 85\% farmers in Rampal used pesticides in shrimp farms. Shrimp farmers (68.29\%) used underground water from nearby canals and underground water to farms if necessary. The shrimp farms $(47.97 \%)$ had water depth in a range of $>3 \mathrm{ft}$ whereas $12.20 \%$ and $39.84 \%$ had the water depth in the range of $<2 \mathrm{ft}$ and $2-3 \mathrm{ft}$ respectively (Table 2 ). 


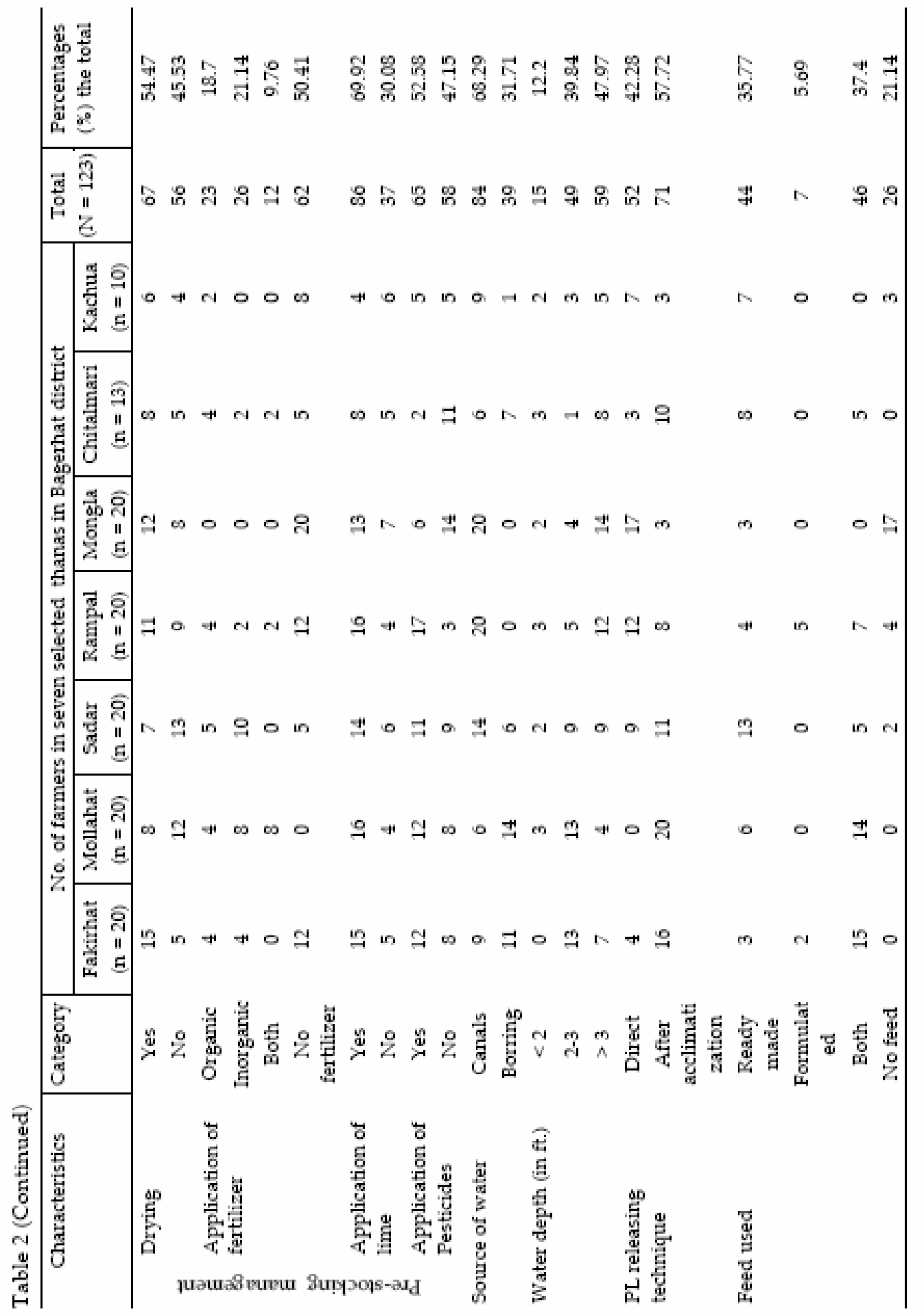




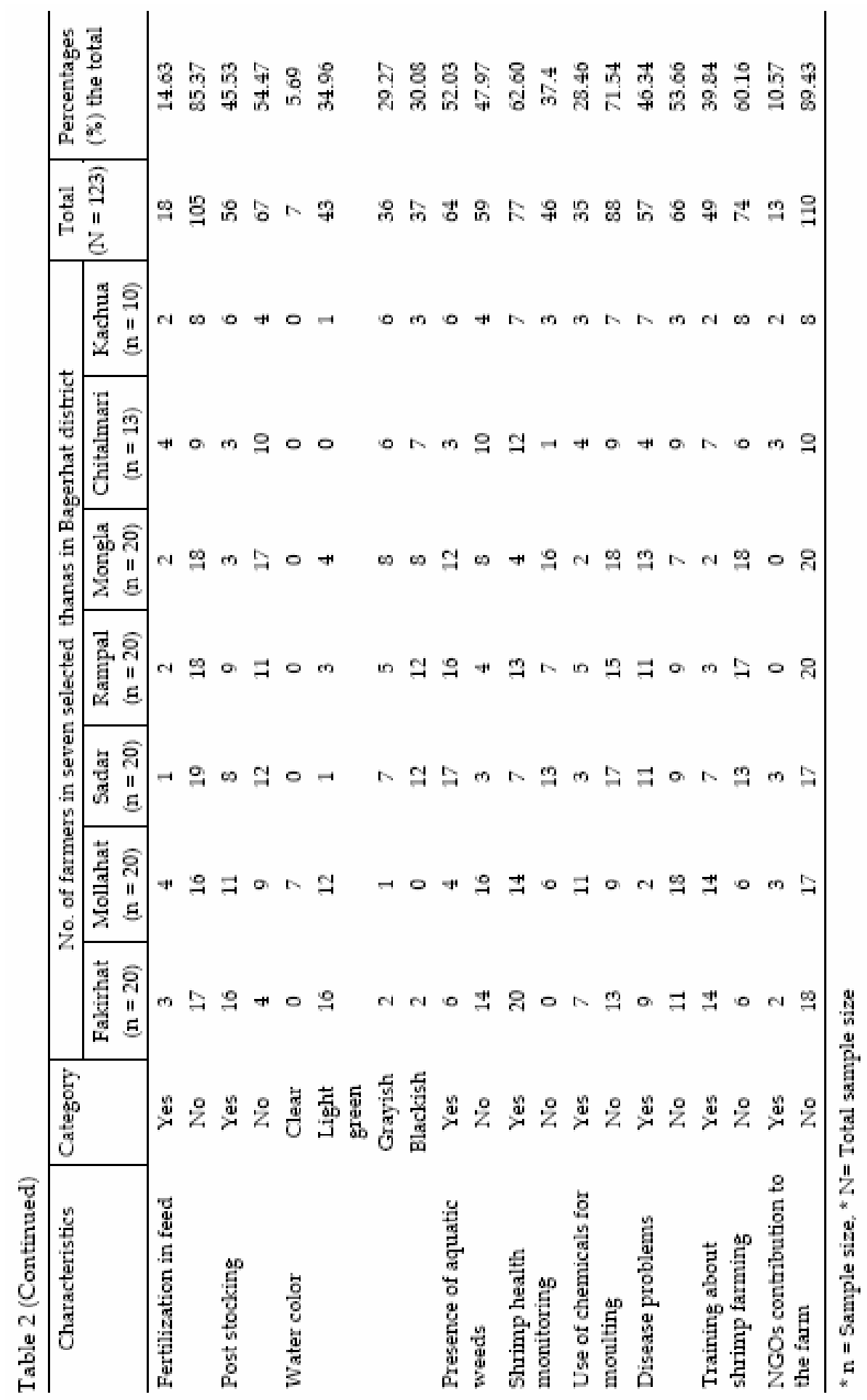


The average stocking density of bagda and golda PL and white fishes were found 24.16, $12.16,0.45$ thousand/ha respectively in the study areas. The highest stocking density of bagda PL was found in Mongla (40.95 thousand/ha) whereas lowest in Mollahat (8.08 thousand/ha) Thana. It was also obsereved that, average 0.45 thousand/ha white fish (fingerlings of Rohu, catla, mrigal, silver carp, grass carp, sarpunti etc.) fries were stocked in the shrimp farms of Bagerhat districts (Table 3).

Water color of $(34.96 \%)$ shrimp ponds were light green whereas $5.69 \%, 29.27 \%$ and $30.08 \%$ farms had clear, grayish and blackish color water respectively. In Sadar Thana $85 \%$ farms had aquatic weeds but no aquatic weeds were available in maximum (80\%) farms in Mollahat. Water quality was monitored by all farmers. Whereas health monitoring were followed by $62.60 \%$ farmers. Most of them used sampling technique for this issue. Among farmers $71.54 \%$ did not use chemicals for moulting of shrimp whereas $53.66 \%$ faced disease problems where maximum infection was noted $(70 \%)$ in Kachua (Table 2).

Harvesting was done using cast nets in small-scale farms where in large-scale farms $(>5$ acres) used ber jal, cast net and sludge gates. During farming financial problems, land, theft, availability of quality PL and muscle power were common problems (Table 4). It was found that $60.16 \%$ farmers had no training before starting of farming but got later from various sources $(39.84 \%)$. Most of the farmers $89.43 \%$ were not interested to take loan from NGOs for their high interest and complexity. In Chitalmari Thana only 23.08\% farmers were involved in taking loan.

In the study area the average annual yields of bagda; golda and white fishes were 350.37, 428.08 and $172.52 \mathrm{~kg} / \mathrm{ha}$. The highest bagda production was found in Mongla (673.34 kg) whereas lowest in Chitalmari Thana $(105.04 \mathrm{~kg})$, similarly the highest production of golda were found in Mollahat Thana $(879.91 \mathrm{~kg})$ lowest $(143.35 \mathrm{~kg})$ in Rampal. White fish gained the highest production at Fakirhat $203.60 \mathrm{~kg} / \mathrm{ha}$ (Table 5).

About $47.97 \%$ shrimp farms had an average depth of water was $>3 \mathrm{ft}$ and other farms had a range of 2-3 ft. So, there was less chances to increase water temperature of shrimp farms and to create stress for prawns. New (2002) suggested that at $0.3 \mathrm{~m}$ water depth of prawn culture system with $34^{\circ} \mathrm{C}$ temperature in sunny noon can cause stress to prawn. However, Mongla and Rampal are situated at the adjacent to the Bay of Bengal and the Sunderbans, naturally water temperature was higher than the other five Thanas of the study area.

The average stocking density of the study was found 36.33 thousand/ha which was almost similar to Thangadurai (1991), who reported the density 30.01 thousand/ha. McGinty and Alston (1993) recommended 25 thousand/ha stocking density for shrimp farming. Whereas Tidwell et al. (1992) indicated a good production with the stocking density of 19.66 thousand/ha. However, white fishes were stocked at 0.44 thousand/ha in shrimp farms in Bagerhat district. Though polyculture was adopted by the maximum farmers in their shrimp culture practices. No additional feeds were supplied to shrimp farms for this white fish. Stocking densities of shrimp PL were higher in all farms as they believed that higher stocking of PL can yield higher production. 


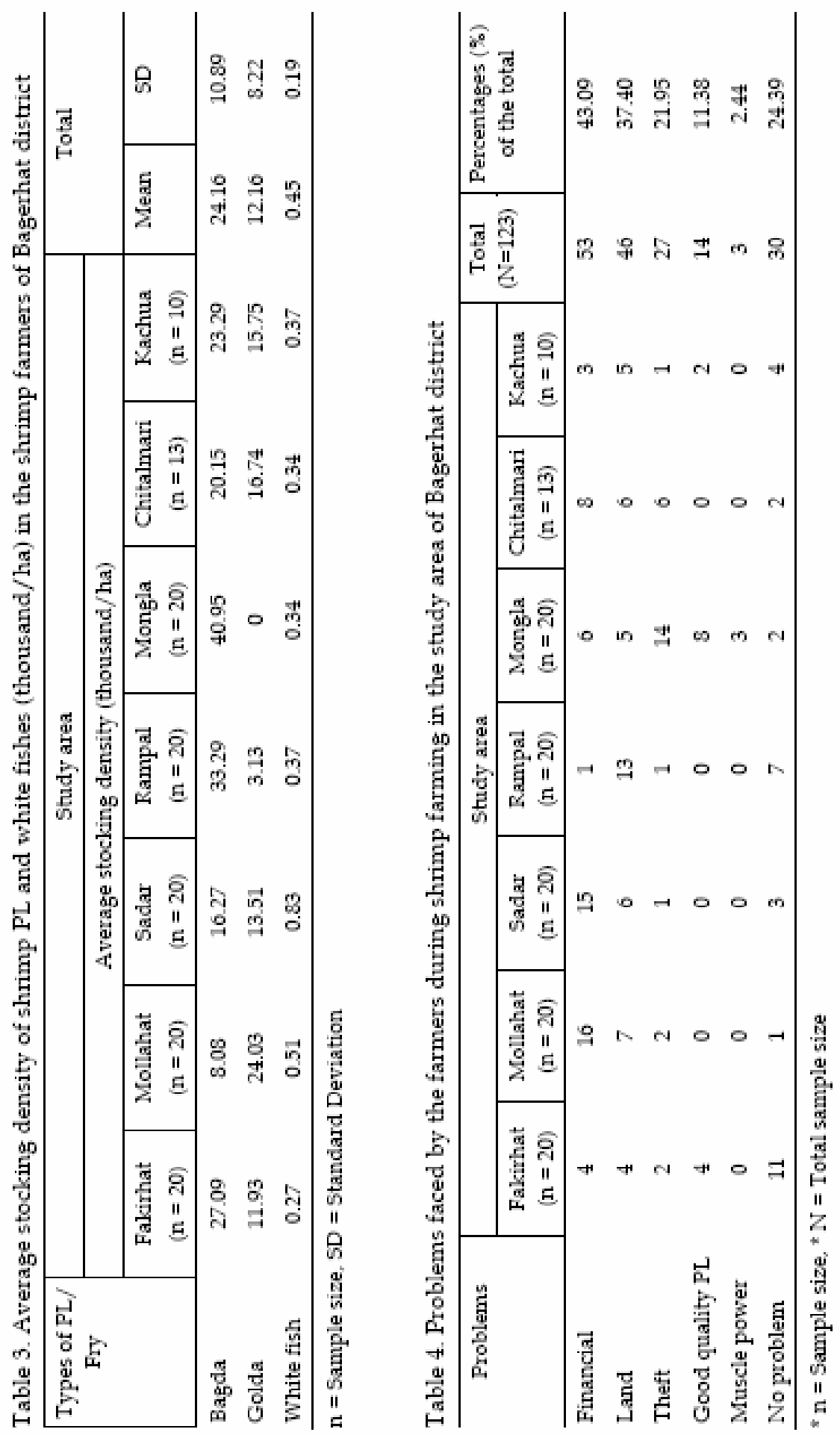


Table 5. Production of shrimp and white fishes $(\mathrm{Kg} / \mathrm{ha})$ in the study areas of Bagerhat district

\begin{tabular}{l|c|cc|c|c|c|c|c|c|}
\hline \multirow{2}{*}{ Types } & \multicolumn{7}{|c|}{ Study area } & \multicolumn{3}{c}{ Total } \\
\cline { 2 - 9 } & \multicolumn{1}{c|}{$\begin{array}{c}\text { Fakirhat } \\
\left(\mathrm{AP}_{1}\right)\end{array}$} & $\begin{array}{c}\text { Mollahat } \\
\left(\mathrm{AP}_{2}\right)\end{array}$ & $\begin{array}{c}\text { Sadar } \\
\left(\mathrm{AP}_{3}\right)\end{array}$ & $\begin{array}{c}\text { Rampal } \\
\left(\mathrm{AP}_{4}\right)\end{array}$ & $\begin{array}{c}\text { Mongla } \\
\left(\mathrm{AP}_{5}\right)\end{array}$ & $\begin{array}{c}\text { Chitalmari } \\
\left(\mathrm{AP}_{6}\right)\end{array}$ & $\begin{array}{c}\text { Kachua } \\
\left(\mathrm{AP}_{7}\right)\end{array}$ & $\begin{array}{c}\text { Mean of average } \\
\text { production } \\
(\mathrm{MAP})\end{array}$ & SD \\
\hline Bagda & 468.08 & 111.39 & 325.27 & 575.18 & 673.34 & 105.04 & 194.31 & 350.37 & 227.65 \\
Golda & 545.22 & 879.91 & 494.66 & 143.35 & 0 & 613.15 & 320.21 & 428.08 & 297.90 \\
White fish & 203.60 & 198.39 & 196.63 & 119.10 & 115.64 & 202.29 & 172.06 & 172.52 & 39.14 \\
\hline
\end{tabular}

* $\mathrm{AP}=$ Average production, ${ }^{*} \mathrm{~S}=\mathrm{No}$. of study areas $(\mathrm{S}=7),{ }^{*} \mathrm{MAP}=$ Mean of average production, ${ }^{*} \mathrm{MAP}=$ $\left(\mathrm{AP}_{1}+\mathrm{AP}_{2}+\mathrm{AP}_{3}+\mathrm{AP}_{4}+\mathrm{AP}_{5}+\mathrm{AP}_{6}+\mathrm{AP}_{7}\right) / \mathrm{S}, * \mathrm{SD}=$ Standard Deviation

Different artificial feeds have been used in shrimp farms which were cooked rice, fishmeal, oil cake, kura, chira, snail muscle etc. Boonyaratpalm and New (1993) obtained better production when used soybean meal, cornmeal, broken rice and rice bran in shrimp farming. William et al. (1995) reported a production of 1,024 -1,662 kg/ha of prawn fed with formulated diet. Tidwell et al. (1993) got suitable production using fishmeal, oilcake and rice bran.

About $53.66 \%$ shrimp farms were attacked by several diseases - P. monodon baculovirus (MBV), White Spot Syndrome Virus (WSSV), soft shell, tail rot disease etc. Nash et al. (1988) reported MBV in P. monodon in brackish water pond and mortalities occurred $(90 \%)$ within 2 weeks after infection. Domestic animals, birds, frogs, snakes, crafts and gears used in farms might be the reasons for disease out break from farm to farm. Farmers $(60.16 \%)$ had no training on shrimp farming as Rudramoorthy (1964) observed that the training process brought out a continuous improvement of farm management by the staff. In the study area only $13.82 \%$ farmers could write their names, they were aware about the benefit of training.

Farmers in the study area got $428.08 \mathrm{Kg} /$ ha shrimp production per year, where tiger shrimp production was $350.37 \mathrm{Kg} / \mathrm{ha} /$ year. Similar production rate were also reported by Jose et al. (1992) and Ali et al. (2000). However, Roy et al. (1999) obtained 231 $\mathrm{kg} / \mathrm{ha} / \mathrm{crop}$ P. monodon for a culture period of 149 days. Few differences in production were created due to differences of farm sizes, stocking densities, feed and management skills etc. In some cases the production was higher due to continuous stocking of shrimp PL.

From the investigation, it was identified that lack of money was a single most important problem for shrimp farming. The other problems associated with land, theft, quality of PL and muscle power. Das (1993) and Mahamud (1998) however, mentioned about the problems of shrimp farms which were the non scientific culture methods, lack of credit and quality PL. 


\section{CONCLUSION}

Farmers should have knowledge on different aspects of shrimp culture practices such as, gher preparation, PL collection and stocking, water quality monitoring, fertilization, feed, disease and its control measures, harvesting, marketing etc. for higher production. In general, the production rate of shrimp is very low compared to other countries. However, production can be raised up to 2 to 3 folds by improving culture systems and management practices. Authorities should concern about import of virus infected stocks, disease monitoring, taxation etc. which are important for successful improvement of the traditional gher farming system to achieve sustainable development of the rural shrimp farmers.

\section{ACKNOWLEDGEMENT}

The authors are highly grateful to the shrimp farmers, DoF personnel and NGO's of Bagherhat area who spared their valuable time for providing information, co-operation and necessary contribution.

\section{REFERENCES}

Ahmed, N. 1957. Prawn and prawn fishery of East Pakistan. Government Press. Dhaka, East Pakistan, $31 \mathrm{p}$

Akand, A. M. and Hasan, M. R. 1992. Status of Freshwater Prawn (Macrobrachium sp.). culture in Bangladesh. In: Freshwater Prawn. Silas (ed.) Proceeding of the National Sysposium, Kerala Agricultural University, India. pp. 33-41.

Ali, M. S., Shofiquzzoha, A. F. M. and Ahmed, S. U. 2000. Observation on the production performances of Penaeus monodon with Liza parsia under different cropping system. Bangladesh J. Fish. Res., 4(2): 141-145.

Boonyaratpalm, M. and New, M. B. 1993. On-farm preparation and feeding strategies for marine shrimp and freshwater prawn. In: Proceeding of the FAO/AADCP Regional expert Consultation on Farm-made Aquafeeds. M. B. New, A. G. Tacon and I. Vasavas (eds.). FAO/AADCP, Bangkok, Thailand. pp. 120-134.

Das, L. 1993. Economics of shrimp cultivation in some selected areas of Bangladesh. An M. Sc. Thesis submitted to the Department of Ag. Econ., Bangladesh Agricultural University, Mymensingh. 63 pp.

DFID, 1997. DFID Fisheries Bangladesh, Issue 2-1997. Department for International Development (DFID) of Bangladesh, Dhaka-1212. 18p.

Islam, M. K. 1999. Study on golda (Macrobrachium rosenbergii) culture system in Mollahat Thana under the management of CARE, Bangladesh. A B. Sc. Thesis submitted to the Discipline of Fisheries and Marine Resource Techonology, Khulna University, Khulna. 46 pp.

Jose, S., Nair, C. M. and Thampy, D. M. 1992. Culture of Macrobrachium rosenbergii in homestead ponds. Freshwater Prawn. E. G. Silas (ed.). Kerala Agricultural University, Thrissur, India. pp. 200-205. 
Kendrick, A. 1994. The gher revolution : the social impact of technological change in Freshwater Prawn cultivation in southern Bangladesh. The report of a social impact assessment prepared for CARE international in Bangladesh with support from the Bangladesh Agriculture and Fisheries Resources Unit (BAFRU). 67 p.

Khanom, D. A. 1999. Study of Golda (Macrobrachium rosenbergii) culture system under the management of CARE, Bangladesh in Dumuria Thana. A B. Sc. Thesis submitted to the Discipline of Fisheries and Marine Resource Technology Discipline, Khulna University, Khulna. pp. 1- 42.

Mahmud, H. 1998. A comparative analysis of rice-cum-prawn and fish-cum-prawn culture in some selected areas under Sadar of Gopalgong district. An M. Sc. thesis submitted to the Department of Ag. Econ., Bangladesh Agricultural University, Mymensingh. 67 pp.

McGinty, A. S. and Alston, D. E. 1993. Multiple stocking and Multiple harvesting of Macrobrachium rosenbergii and tilapia. In: M. Carrillo, L. Dahle, J. Morales, P. Sorgeloos, N. Svennevig, J. Wyban (eds.). From discovery to commercialization. Oost.-Bel. Euro. Aquaculture Soc., 19: 148.

Mitra, G., Chattopadhyay, D. N. and Mukhopadhyay, P. K. 2005. Nutrition and feeding in freshwater prawn (Macrobrachium rosenbergii) farming. Aqua Feeds: Formulation and Beyond, 2:17-19.

Nash, G., Poernomo and Nash, M. B. 1988. Vaculovirus infection in brackish water pond culture Penaeus monodon (Fabricius) Indonesia. Aquaculture 73: 1-6.

New, M. B. 2002. Farming freshwater prawn: a manual for the culture of the giant river prawn (Macrobrachium rosenbergii). FAO Fisheries Technical Paper no. 428, FAO, Rome, Italy. 212 pp.

Roy, P. K., Ahmed, S. U. and Shofiquzzoha, A. F. M. 1999. Optimizing of stocking density for environmental friendly improved extensive shrimp farming system in south-west part of Bangladesh. Bangladesh J. Fish. Res., 3: 137-143

Rudramoorthy, B. 1964. Extension in planned social change, Allied Publishers Private Ltd. 15, Grham Road, Ballard Estate, Bombay. 218 pp.

Thangadurai, A. J. 1991. Experimental culture of freshwater prawn (Macrobrachium rosenbergii) in ponds. In: Proceedings of National Symposium on New Horizons in Freshwater Aquaculture. Central Institute of Freshwater Aquaculture, Bhubaneswar, Orissa, India. pp. 7-8.

Tidwell, J. H., Webster, C. D., Yancy, D. H. and Abramo, L. R. D. 1993. Partial and total replacement of fishmeal with soyabean meal and distillers' by products in diets for pond culture of the freshwater prawns (Macrobrachium rosenbergii). Aquaculture, 118 (1-2): 119-130.

Tidwell, J. H., Webster, C. D., Clark, J. A. and Abramo, L. R. D. 1992. Evaluation of distillers dried grains with soluble as a protein source in diets for the freshwater prawn, Macrobrachium rosenbergii Aquaculture' 92: Growing towards the 21 ${ }^{\text {st }}$ century. pp. 216-217.

William, H. D., Abramo, L. R. D., Fondren, M. W. and Duran, M. D. 1995. Effects of stocking density and feed on production characteristics and revenue of harvested freshwater prawns Macrobrachium rosenbergii stocked as size-graded juveniles. J. World Aquaculture Soc., 26(1): 38-47. 